\title{
INVESTIGATION OF THE EFFECT OF ADDITION OF BORON NITRIDE ON MICROSTRUCTURE AND MECHANICAL PROPERTIES OF CAST IRON BRAKE MATERIALS USED IN RAILWAY VEHICLES
}

\author{
CUG Harun ${ }^{1 *}$, Dr., Assist. Prof., \\ ASGAROV Khangardash ${ }^{2 *}$, Dr., Prof., \\ TIGCI Gülcan ${ }^{3}$ \\ DURSUNLAR Mustafa ${ }^{4}$, Ass. \\ 1* Mechanical Engineering Department, Karabuk University, Karabuk, Turkey, e-mail: hcug@karabuk.edu.tr \\ ${ }^{2 *}$ Mechanical Engineering Department, Karabuk University, Karabuk, Turkey, tel. +90 (538) 455-04-45, e-mail: askerov56@mail.ru, \\ ORCID ID: 0000-0003-4771-3406 \\ ${ }^{3}$ Kardemir Iron and Steel Factory, Karabuk, Turkey \\ ${ }^{4}$ Sorgun Vocational School, Bozok University, Sorgun, Turkey
}

\begin{abstract}
In this study, characterization of cast iron break shoes used in locomotives and the effect of BN addition and $\mathrm{BN}$ addition on microstructure and mechanical properties by using powder metallurgy (PM) method by adhering to the chemical composition of cast iron break shoes were investigated. In this context, cast iron sabers were chemically analyzed and all elements were supplied in powder form, and then BN added powder compositions were produced by cold and hot pressing technique. A total of 4 different compositions were created without BN, with $0.25,0.5$ and $1 \%$ $\mathrm{BN}$ addition. Cold pressing was made in a steel mold with a diameter of $10 \mathrm{~mm}$ under $700 \mathrm{MPa}$ pressure under room conditions. Hot pressing was carried out in a graphite mold with a diameter of $15 \mathrm{~mm}$ in an argon atmosphere under a pressure of $45 \mathrm{MPa}$ at a temperature of $900{ }^{\circ} \mathrm{C}$. Then the cold and hot pressed samples were sintered at $1200{ }^{\circ} \mathrm{C}$ for 2 hours in argon atmosphere. Density measurement of the produced compositions, microstructure examination, micro hardness measurement were made. Generally, in density measurements, the densities of the samples subjected to hot pressing were higher than the cold pressing process. The hardness value decreased in parallel with the addition of $\mathrm{BN}$.
\end{abstract}

Keywords: Brake shoe; powder metallurgy; microstructure; mechanical properties

\section{ДОСЛІДЖЕННЯ ВПЛИВУ ДОДАВАННЯ НІТРИДУ БОРУ НА МІКРОСТРУКТУРУ ТА МЕХАНІЧНІ ВЛАСТИВОСТІ МАТЕРІАЛІВ ЧАВНОГО ТОРМОЗУ, ЩО ВИКОРИСТОВУЄТЬСЯ В ЗАЛІЗНИЧНИХ КОЛЕСАХ}

\author{
КЮГ Аарон ${ }^{1 *}$, докт., асист. проф., \\ АСГАРОВ Хангардаш ${ }^{2 *}$, докт., проф., \\ ТІДЖІ Гулкан ${ }^{3}$ \\ ДУРСУНЛАР Мустафа ${ }^{4}$, acuсm. \\ ${ }^{1 *}$ Кафедра машинобудування, Університет Карабюк, Карабук, Туреччина, e-mail: hcug@karabuk.edu.tr \\ ${ }^{2 *}$ Кафедра машинобудування, Університет Карабюк, Туреччина, тел. +90 (538) 455-04-45, e-mail: askerov56@mail.ru, \\ ORCID ID: 0000-0003-4771-3406 \\ ${ }^{3}$ Кардемірський металургійний завод, Карабюк, Туреччина \\ ${ }^{4}$ Професійне училище Соргун, Університет Бозок, Соргун, Туреччина
}

Анотація. Постановка проблеми. Надано характеристику чавунних ломових башмаків, що використовуються в локомотивах, та вивчено вплив додавання нітриду бору (BN) на механічні властивості методом порошкової металургії (ПМ) шляхом дотримання хімічного складу чавунних ломових башмаків. У цьому контексті чавунні шаблі хімічно аналізували, і всі елементи поставляли у вигляді порошку, а потім порошкові композиції з додаванням ВN виготовляли методом холодного та гарячого пресування. Всього було створено чотири різні композиції без $\mathrm{BN}$, з додаванням $0.25,0.5$ та 1 \% BN. Холодне пресування здійснювали у сталевій формі діаметром 10 мм під тиском 700 МПа в кімнатних умовах. Гаряче пресування здійснювали в 
графітовій формі діаметром 15 мм в атмосфері аргону за тиску 45 МПа за температури $900{ }^{\circ} \mathrm{C}$. Потім зразки холодного та гарячого пресування спікали за $1200{ }^{\circ} \mathrm{C}$ протягом 2 годин в атмосфері аргону. Виконано вимірювання щільності вироблених композицій, мікроструктурне дослідження, мікротвердість. Як правило, під час вимірювання щільності зразків, підданих гарячому пресуванню, була вищою, ніж за холодного пресування. Значення твердості зменшувалось паралельно з додаванням BN.

Ключові слова: гальмівна колодка; порошкова металургія; мікроструктура; механічні властивості

Introduction. Brakes; Used in railway vehicles to slow down, control acceleration (downhill) or to keep them stable when parked. The first railway vehicles with braking systems were small freight cars running on rails in mines. Miners used a lever system to push a wooden block against the wheel. However, such manual brakes were insufficient as the mass and speed of the railroad vehicle increased. For this reason, braking systems using motion power have been developed $[1 ; 2]$.

Railway vehicles, which are generally designed to operate below $160 \mathrm{~km} / \mathrm{h}$, are

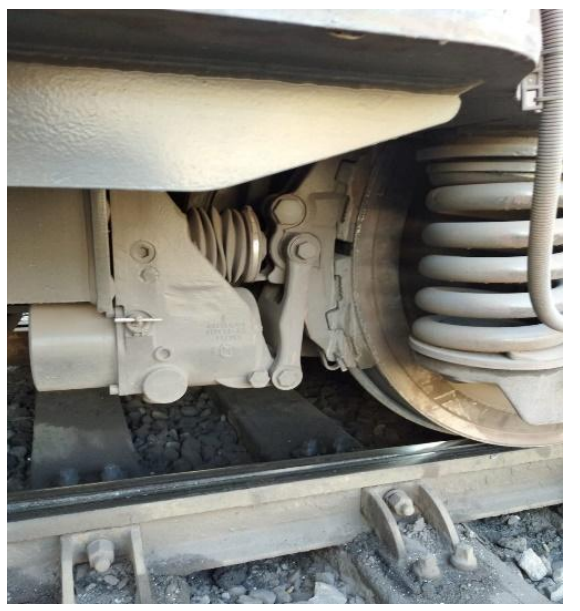

equipped with a surface brake system based on a relatively simple mechanism that is efficient, safe and low cost $[2 ; 3]$.

Brake blocks, which are an important component for traffic safety, must meet certain requirements, such as a high and constant coefficient of friction, regardless of speed, specific pressure, temperature and environmental conditions. Low wear rate, lightness, low noise and corrosion resistance, and suitable thermodynamic properties are also desirable properties [4-6].

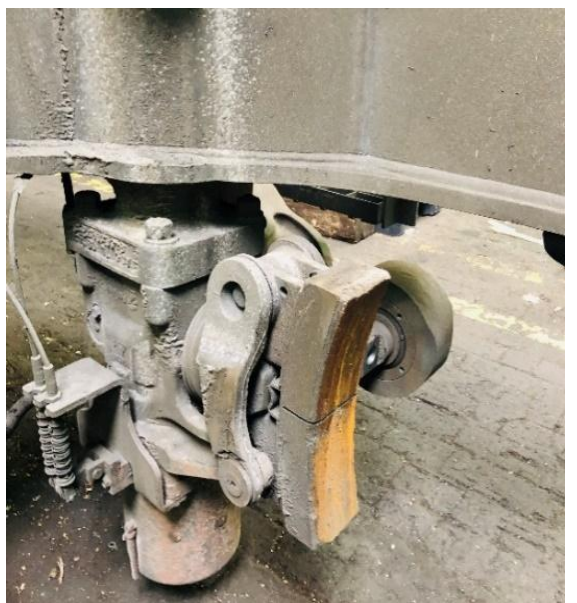

Fig. 1. Composite break shoe used in DE10000 Tülomsaş locomotives in Kardemir

Break shoes are made of cast iron or composite material according to special manufacturing instructions. They should be softer than the wheel material. Its thickness is generally $60 \mathrm{~mm}$ and it can be used up to a thickness of $10 \mathrm{~mm}$. They can be manufactured in one or two pieces. In two-piece break shoes, the part to which the break shoe is attached is called shoe (shoe). It is also possible to attach more than one break shoe to the same shoe. Recently, sabers made of composite material are preferred due to their durability, lightness and ease of change.

Currently, 3 types of break shoes are used for freight wagons in rail transport. These are cast (P10), K and LL type break shoes. Casting break shoe (P10) specifications are defined in the UIC-832 plug, it has been used in freight wagons for a long time and is made of gray cast iron. $\mathrm{K}$ and LL type break shoe has been developed in the last 10 years and is manufactured from composite material.

Boron nitride, which is in the structure of cubic crystal, is known to be one of the hardest elements after diamond and it is also an excellent lubricant in high temperature applications due to its hexagonal lattice structure. However, the only good thing about hexagonal boron nitride is that it is not a lubricant; High thermal conductivity, thermal 
shock resistance, smooth surface output, refractory properties, inertness, low wettability, non-toxic and clean material are the advantages that encourage the use of hexagonal structured boron nitride [8-11].

Most of the PM pieces have a porous structure. This makes the PM method ideal for making self-lubricating bearings in which the surface-bound pores of the parts are impregnated with oil. Oil is released through the pores when the bearing surface gets hot due to the heat of friction. When the bed cools, the oil is sucked back into the pore channels by capillary action. The porosity of the PM parts has an effect on the physical, mechanical, magnetic, thermal, wear and corrosion properties of the parts [8-11].

In this study, characterization of cast iron break shoes used in locomotives and the effect of $\mathrm{BN}$ addition and $\mathrm{BN}$ addition on microstructure and mechanical properties by using PM method by adhering to the chemical composition of cast iron break shoes were investigated.

Experimental studies. An important part of the experimental work environment was carried out in Karabük University, Iron and Steel Institute, MARGEM Laboratories. RADWAG AS-60-220 C/2 precision scales were used for weighing powders and for both and post-sintering density measurements of the produced samples. A hydraulic press with a capacity of 100 tons is used for pressing BN powders. The powders required for the production of BN added break shoe have been supplied and their properties such as powder size and purity value are given in Table 1 .

Table 1

Powders and their properties

\begin{tabular}{|c|c|c|c|}
\hline & Powder & Powder Size & \% Purity Value \\
\hline 1 & $\mathrm{BN}$ & $<1 \mathrm{~nm}$ & 98,00 \\
\hline 2 & $\mathrm{Al}$ & $40 \ldots 50 \mathrm{~nm}$ & 99,99 \\
\hline 3 & $\mathrm{C}$ & $40 \ldots 50 \mathrm{~nm}$ & 99,99 \\
\hline 4 & $\mathrm{Mn}$ & $40 \ldots 50 \mathrm{~nm}$ & 99,99 \\
\hline 5 & $\mathrm{Ni}$ & $40 \ldots 50 \mathrm{~nm}$ & 99,99 \\
\hline 6 & $\mathrm{Si}$ & $40 \ldots 50 \mathrm{~nm}$ & 99,99 \\
\hline
\end{tabular}

The compositions produced were subjected to density measurement, microstructure examination, micro hardness measurement and dry wear test. The powders supplied were weighed with a precision of 0.0001 gr with precision scales at the proportions given in the chemical composition in Table 2. The weighed powders were mixed for 1 hour.

The compositions to be produced have been produced by two different methods. The first of these is cold pressing in this method, after the mixing process, the powders were pressed in a steel mold with a diameter of $10 \mathrm{~mm}$ with the help of a hydraulic press under $700 \mathrm{MPa}$ pressure. The second method is the hot pressing method. In this method, the composition produced after cold pressing and having the highest hardness was selected and that composition was produced in hot press.
Powders prepared by hot pressing were compressed in a graphite mold at $900{ }^{\circ} \mathrm{C}$ under $45 \mathrm{MPa}$ pressure in an atmosphere controlled oven.

Table 2

Chemical composition of powders used for composite material production

\begin{tabular}{|c|c|c|c|c|c|}
\hline Compounds & $\begin{array}{c}\text { BN } \\
(\% \mathbf{\% t})\end{array}$ & $\begin{array}{c}\mathbf{C} \\
(\mathbf{\% w t})\end{array}$ & $\begin{array}{c}\mathbf{M n} \\
(\mathbf{\% w t})\end{array}$ & $\begin{array}{c}\mathbf{S i} \\
(\mathbf{\% w t})\end{array}$ & $\begin{array}{c}\mathbf{F e} \\
(\mathbf{\% w t})\end{array}$ \\
\hline $\begin{array}{c}\text { Sample } \\
\text { No. 1 }\end{array}$ & 0 & 3,56 & 0,943 & 2,204 & balance \\
\hline $\begin{array}{c}\text { Sample } \\
\text { No. 2 }\end{array}$ & 0,25 & 3,56 & 0,943 & 2,204 & balance \\
\hline $\begin{array}{c}\text { Sample } \\
\text { No. 3 }\end{array}$ & 0,5 & 3,56 & 0,943 & 2,204 & balance \\
\hline $\begin{array}{c}\text { Sample } \\
\text { No. 4 }\end{array}$ & 1 & 3,56 & 0,943 & 2,204 & balance \\
\hline
\end{tabular}

A press with a capacity of 100 tons was used for pressing. Before pressing, 15...20 gr 
powder mixture was put into the mold. After pressing, a sample of approximately $20 \mathrm{~mm}$ in height, 10 and $15 \mathrm{~mm}$ in diameter was obtained. Sintering processes of the produced samples were carried out in argon atmosphere. Hot pressed samples were hot pressed at $900{ }^{\circ} \mathrm{C}$ and then subjected to sintering process at $1200{ }^{\circ} \mathrm{C}$ in argon atmosphere with all other samples.

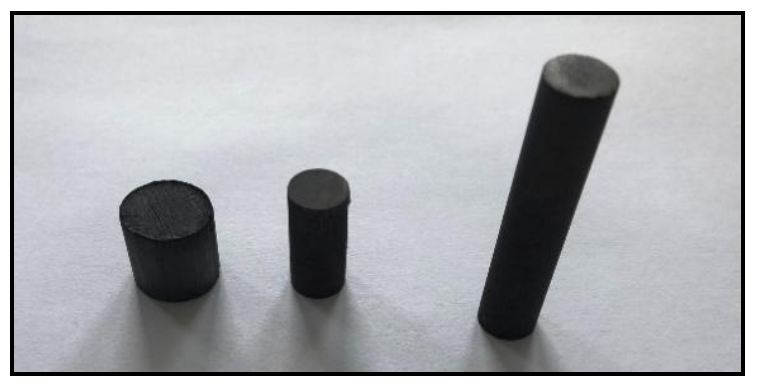

Fig. 2. Plain alloy and BN reinforced composite materials sintered

Microstructural examinations were carried out with a Nikon Eclipse MA 200 brand optical microscope with X25-X1500 magnification, located in KARDEMIR A.Ş, Quality Metallurgy and Laboratories Directorate,
Mechanical Physics and Test Laboratory. Two $200 \mu(100 \times), 350 \mu(500 \times)$ sized images were taken from different parts of the four samples produced, and importance was given to the quality of these images representing the entire microstructure. SEM examinations were carried out in Karabük University, Iron and Steel Institute, MARGEM laboratory.

Experimental results and discussion. The density generally decreased with the addition of boron nitride. When the densities of the samples obtained by cold pressing are compared, it is seen that the sample without BN added has the highest density, and the $1 \% \mathrm{BN}$ added sample has the lowest density. When the samples obtained by hot and cold pressing are compared, it is seen that the sample obtained by hot pressing has the highest density and its density is higher than the sample obtained by cold pressing. In addition, it is seen that the sample obtained by hot pressing is higher than the density of the related five samples. The reason for this can be interpreted as the density increasing effect of hot pressing on the sample.

Table 3

Density and harness measurement results

\begin{tabular}{|c|c|c|}
\hline Sample & Density $\left(\mathrm{gr} / \mathrm{cm}^{3}\right)$ & $\begin{array}{c}\text { Average Hardness } \\
(\text { HV0.5) }\end{array}$ \\
\hline Cold pressed Without BN & 6,252 & 123,6 \\
\hline Cold pressed \% 0,25 BN & 6,241 & 117,8 \\
\hline Cold pressed \% 0,5 BN & 6,221 & 111,4 \\
\hline Cold pressed \% 1 BN & 6,193 & 105,5 \\
\hline Hot pressed \% 1 BN & 6,357 & 116,4 \\
\hline
\end{tabular}

When the relevant Table 3 is examined; It is seen that the hardness of the sample without $\mathrm{BN}$ addition is the highest compared to the other samples with $\mathrm{BN}$ addition. When the $\mathrm{BN}$ added samples are compared with each other, the increase of the $\mathrm{BN}$ addition amount decreases the hardness. Therefore, the sample with the highest $\mathrm{BN}$ addition has the lowest hardness value among the samples. However, it can be said that the sample obtained by hot pressing has an average hardness compared to other samples in the study, since hot pressing increases the hardness. The addition of BN decreases the hardness, and the temperature increases the falling hardness value with the addition of $\mathrm{BN}$. When comparing the $1 \% \mathrm{BN}$ added sample hardness obtained by hot and cold pressing, it is seen that the hot-pressing sample hardness is higher than the cold pressing sample hardness. In summary, the sample with the highest hardness among the relevant samples is the one without the addition of BN. The sample with the lowest hardness is the cold pressed sample with $1 \% \mathrm{BN}$ added. 


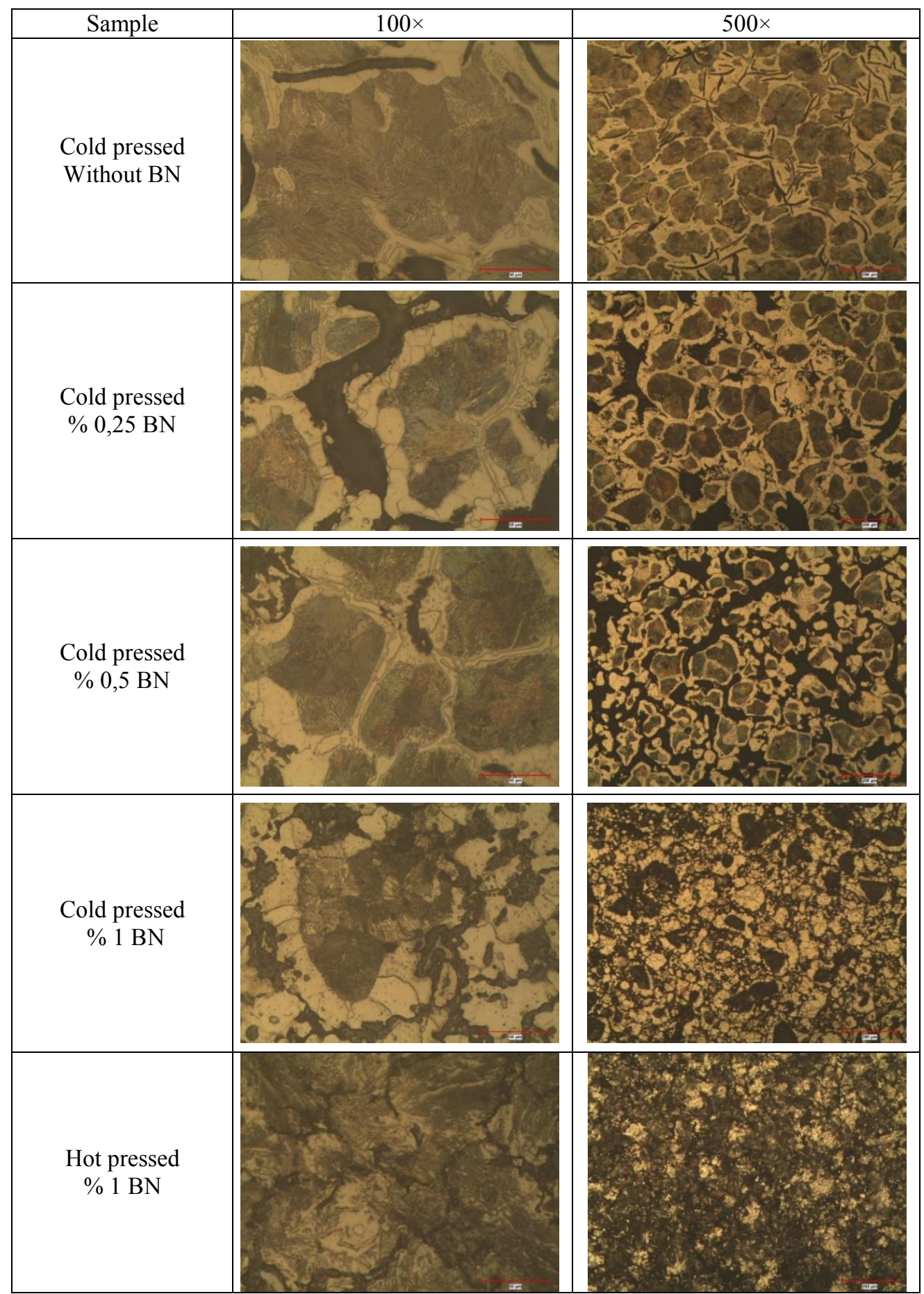

Fig. 3. Optical microstructure images $(100 \times$ and $500 \times)$

Comparing cold pressing to each other; It is seen that as the amount of boron nitride addition increases, the grain size in the structure decreases. It is clearly seen in the microstructure that the grain size decreases with the addition of boron nitride amount from 0 to $1 \%$. In addition, another reason for the strength increase is thought to be a second reason for the strength increase due to the formation of the added Boron Nitride precipitates in the grain and at the grain boundaries. The addition of boron nitride contributes to the strength because it prevents the dislocation movement in the grain and at the grain boundaries and prevents the grain growth.

In addition, grain growth was observed during the sintering process when cold pressed Boron Nitride and hot pressed $1 \%$ Boron Nitride were compared. It can be explained that 
this caused a decrease in hardness and wear values.

The rationale is to make an additional sintering at $1300{ }^{\circ} \mathrm{C}$ after hot pressing at $900{ }^{\circ} \mathrm{C}$, reducing the growth of Boron Nitride precipitates and preventing dislocation movements. In addition, the sintering temperature causes grain growth with a second sintering, causing a decrease in strength.

General results. In this study, microstructural characterization and mechanical tests of the samples produced by adding $\mathrm{BN}$ to the break shoe produced by powder metallurgy method were carried out. The general results obtained and the recommendations made in the light of these results are given below.
According to the microstructure results; Grain size increases with hot pressing. This situation causes the strength to decrease. Therefore, high sintering temperature decreases the strength.

According to the density and hardness results; The density and hardness decreased with the addition of $\mathrm{BN}$. The decrease in hardness and density occurred in samples obtained by cold pressing. BN added hot pressing caused an increase in density and hardness, unlike BN added cold pressing. The density of the BN added sample obtained by hot pressing reached the highest value. In hardness, the hardness of the BN added sample obtained by hot pressing has an average hardness compared to other samples.

\section{REFERENCES}

1. Bureika G. and Mikaliunas S. Research on the compatibility of the calculation methods of rolling-stock brakes. Transport. 2008, no. 23 (4), pp. 351-355.

2. Hasegawa I. and Uchida S. Railway technology today 7. Braking systems. Japan Railway \& Transport Review (JRTR). 1999, no. 20, pp. 52-29.

3. Sharma R.C., Pathak R.K. and Dhingra M. Braking system in railway vehicle. International Journal of Engineering Research \& Technology (IJERT). 2015, no. 4 (1), pp. 206-211.

4. Zhang Z. and Dhanasekar M. Dynamics of railway wagons subjected to braking/traction torque. Vehicle System Dynamics. 2009, no. 47 (3), pp. 285-307.

5. Liudvinavicius L. and Lingaitis L.P. Electrodynamic braking in high-speed rail transport. Transport. 2007, no. 22 (3), pp. $178-186$.

6. Cruceanu C. and Craciun C. Aspects regarding the braking capacity of composite brake shoes for railway vehicles. Materiale Plastice. 2019, no. 56 (1), pp. 18-21.

7. Akbayır Ö. Yük vagonlarında kullanılan break shoe çeşitleri ve karşılaştırması. Uluslararası Raylı Sistemler Mühendisliği Çalıştayı (IWRSE'12). 2012.

8. Tadayuki T. Recent technology of powder metallurgy and applications. Hitachi Chemical Technical Report 2012, no. 54, pp. 12-20.

9. Erden M.A. Toz metalurjisi yöntemiyle üretilen mikroalaşım çeliklerinin mikroyapı mekanik özellik ilişkisinin araştırılması. Doktora Tezi, Karabük Üniversitesi Fen Bilimleri Enstitüsü. 2015.

10. German R.M. Powder metallurgy \& particulate materials processing. Metal Powder Industries Federation. Princeton, NJ, 2005

11. Erden M.A., Türkmen M., Karabulut H. and Gündüz S. Effect of Boron Nitride Addition on the Microstructure and Mechanical Properties of PM Steels. AKÜ FEMÜBİD, 2017, no. 17, pp. 185-191.

Надійшла до редакції : 13.04.2021. 